\title{
Bat-species richness in the Pantanal floodplain and its surrounding uplands
}

\author{
Alho, CJR. ${ }^{\text {** }}$ Fischer, E. ${ }^{\mathrm{b} *}$, Oliveira-Pissini, LF. ${ }^{\mathrm{*} *}$ and Santos, $C F^{\mathrm{d} *}$ \\ aPrograma de Pós-graduação em Meio Ambiente e Desenvolvimento Regional, Universidade Anhanguera - Uniderp, \\ CEP 79037-280, Campo Grande, MS, Brazil

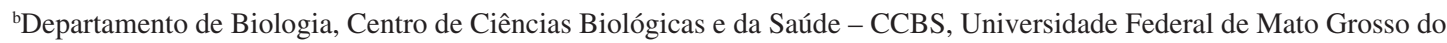 \\ Sul - UFMS, CEP 79070-900, Campo Grande, MS, Brazil \\ 'Programa de Pós-graduação em Meio Ambiente e Desenvolvimento Regional, Universidade Anhanguera - Uniderp, \\ CEP 79037-280, Campo Grande, MS, Brazil \\ 'Programa de Pós-graduação em Ecologia e Conservação, Centro de Ciências Biológicas e da Saúde - CCBS, \\ Universidade Federal de Mato Grosso do Sul - UFMS, CEP 79070-900, Campo Grande, MS, Brazil \\ *e-mail: alho@unb.br, eafischer@uol.com.br, larybio@yahoo.com.br, santoscaro@gmail.com \\ Received October 14, 2010 - Accepted December 13, 2010 - Distributed April 30, 2011
}

(With 5 figures)

\begin{abstract}
We studied the bat fauna of the Pantanal floodplain and its surrounding plateaus in Mato Grosso do Sul, Brazil, based on the scientific collection at Universidade Anhanguera - Uniderp and on the Projeto Morcegos do Pantanal data bank at UFMS, comprising 9,037 captures of 56 species recorded from 1994 to 2007 . The Pantanal surveys were carried out in the Nhecolândia, Aquidauana, Miranda, and Paraguai sub-regions; the uplands surveys took place in the Maracaju, Bodoquena, and Urucum formations. Bat specimens were mist-netted over 376 nights in 35 sites, predominantly near fruiting trees, bat shelters, and forest patches. In the floodplain 46 species were recorded $(n=6,292$ individuals), and 44 species were found in the uplands ( $n=2,745$ individuals). Six families were recorded: Phyllostomidae ( 30 species), Molossidae (12 species), Verpertilionidae (nine species) Noctilionidae (two species), Emballorunidae (two species) and Mormoopidae (one species). The bat fauna was predominantly composed of insectivore (32) and frugivore (15) species. The frugivorous Artibeus planirostris ( $\mathrm{n}=3,101$ individuals) was the commonest species in floodplain and uplands. Other common species were Myotis nigricans $(\mathrm{n}=762)$, Molossus molossus $(\mathrm{n}=692)$, Noctilio albiventris $(\mathrm{n}=681)$, Platyrrhinus lineatus $(\mathrm{n}=633)$, Sturnira lilium $(\mathrm{n}=461)$, Carollia perspicillata $(\mathrm{n}=451)$, Glossophaga soricina ( $\mathrm{n}=436)$, Artibeus lituratus $(\mathrm{n}=320)$, and Desmodus rotundus $(\mathrm{n}=281)$. In the floodplain there were three insectivores among the most common species, contrasting with the uplands dominated by the frugivores. The diversity for the 35 sites assembled $\left(H^{\prime}=2.5\right)$ is comparable to that recorded for tropical forests. The bat fauna presented here represents $34 \%$ of the Brazilian bat species, and $62 \%$ of species reported for the Upper Paraguay River Basin. Additionally, five species are reported for the first time in Mato Grosso do Sul.
\end{abstract}

Keywords: bats, biodiversity, Chiroptera, habitats, Pantanal.

\section{Riqueza de espécies de morcegos no Pantanal e no planalto em seu entorno}

\section{Resumo}

Estudamos a fauna de morcegos na planície do Pantanal e nos planaltos de entorno no Mato Grosso do Sul, Brasil, com base na coleção científica da Universidade Anhanguera - Uniderp e no banco de dados do Projeto Morcegos do Pantanal, UFMS, incluindo 9.037 capturas de 56 espécies, entre 1994 e 2007. Amostragens no Pantanal foram feitas nas sub-regiões da Nhecolândia, Aquidauana, Miranda e Paraguai; no planalto as amostragens foram realizadas nas formações de Maracaju, Bodoquena e Urucum. Espécies de morcegos foram registradas ao longo de 376 noites em 35 sítios, predominantemente com o uso de redes de neblina próximas a árvores frutíferas, abrigos e florestas. Na planície, foram registradas 46 espécies $(n=6.292$ indivíduos $)$ e no planalto 44 espécies $(n=2.745$ indivíduos). Seis famílias foram encontradas: Phyllostomidae (30 espécies), Molossidae (12 espécies), Verpertilionidae (nove espécies), Noctilionidae (duas espécies), Emballorunidae (duas espécies) e Mormoopidae (uma espécie). A fauna de morcegos foi predominantemente composta de espécies insetívoras (32) e frugívoras (15). O frugívoro Artibeus planirostris $(\mathrm{n}=3.101)$ foi a espécie mais comum na planície e no planalto. Outras espécies comuns foram Myotis nigricans $(\mathrm{n}=762)$, Molossus molossus $(\mathrm{n}=692)$, Noctilio albiventris $(\mathrm{n}=681)$, Platyrrhinus lineatus $(\mathrm{n}=633)$, Sturnira lilium $(\mathrm{n}=461)$, Carollia perspicillata $(\mathrm{n}=451)$, Glossophaga soricina $(\mathrm{n}=436)$, Artibeus lituratus $(\mathrm{n}=320)$ e Desmodus rotundus $(\mathrm{n}=281)$. Na planície, ocorreram três espécies de morcegos insetívoros dentre as espécies mais comuns, contrastando com o planalto, onde houve dominância de frugívoros. A diversidade para os 35 sítios reunidos $\left(H^{\prime}=2,5\right)$ é comparável à encontrada em florestas tropicais. A fauna de morcegos apresentada aqui representa $34 \%$ das espécies brasileiras, e $62 \%$ das espécies já reportadas para a Bacia do Alto Paraguai. Adicionalmente, cinco espécies são reportadas pela primeira vez no Mato Grosso do Sul.

Palavras-chave: morcegos, biodiversidade, quirópteros, hábitats, Pantanal. 


\section{Introduction}

Bats are often the most species-rich mammalian taxonomic group in the tropics (Patterson et al., 2001) and represent nearly one-third of Brazilian land fauna (Marinho-Filho and Sazima, 1998). Different studies have shown latitudinal gradients contributing to the understanding of geographic distribution of bat diversity, by analysis of species richness patterns on a large scale, across wide spatial areas or with regional focus (Rohde, 1992; Willig, 2000; Stevens and Willig, 2002). Another approach is to examine changes in species richness along environmental gradients, when an assemblage of interacting bat species utilizes the same resource, for example seasonal productivity, which is carried out on smaller spatial scales (Alho, 2008; Drobner et al., 1998; Wilsey and Potvin, 2000). Some environmental factors limit the occurrence and abundance of some species, including habitat heterogeneity, seasonality and conservation status (Alho, 2005; Keddy et al., 2009).

Bat communities exhibit a variety of functional groups (guilds) such as insectivores, frugivores, nectarivores, sanguivores and piscivores (Stevens and Willig, 2002). Some studies have shown these bat assemblages in different areas: trophic relations in the Phyllostomidae from Panga Reserve, southeastern Brazil (Pedro and Taddei, 1997); bat community structure in a south-east Brazilian reserve in a transition zone between Cerrado and Atlantic Forest (Falcão et al., 2003); diversity of a Cerrado habitat in central Brazil (Zortéa and Alho, 2008). Recent literature has synthesised the number of species and distribution in Brazil (Reis et al., 2007), as well as a bat community in a savanna habitat in Bolivia, near the Pantanal (Willig et al., 2000; Aguirre, 2002). Available data on bats of the Pantanal floodplain and its neighbouring uplands, particularly from Mato Grosso do Sul state, are reported in Leite et al. (1998, 2000), Taddei et al. (2000, 2001, 2003), Camargo and Fischer (2005), Gonçalves et al. (2007), Longo et al. (2007), Camargo et al. (2009), Cunha et al. (2009), and Teixeira et al. (2009).

Large and environmentally heterogeneous wetlands like the Pantanal $\left(147,574 \mathrm{~km}^{2}\right.$ - latitude $15^{\circ} 30^{\prime}-22^{\circ} 30^{\prime} \mathrm{S}$ and longitude $54^{\circ} 45^{\prime}-58^{\circ} 30^{\prime} \mathrm{W}$ ), exhibiting annual changes in evenness along environmental gradients, play an important role in biological diversity, because of the heterogeneity of natural habitats, offering opportunities for feeding and reproductive niches (Alho, 2008; Keddy et al., 2009). Differences in bat species abundance may respond to local environmental annual changes or to degree of habitat degradation. Because the Pantanal and its surrounding habitats harbour a large number of bat species, some common (high abundance) and some relatively rare, intensive survey efforts are needed to estimate confidently the species abundance distributions.

The aim of this study is to show the magnitude of the bat species richness and the structure of the community, evaluating relative abundance and trophic distribution within the Pantanal floodplain and throughout its surrounding
Cerrado plateaus, as well as to discuss the present status of natural habitat conservation and their bat-associated species.

\section{Methods}

\subsection{Study sites}

\subsubsection{Pantanal flood plain and surrounding uplands}

The maze of fluctuating water levels, nutrients, and biota in the Pantanal forms a dynamic ecosystem (Alho, 2008). The degree of inundation creates a range of major habitats. Flooding occupies about $80 \%$ of the whole Pantanal. In contrast, during the dry season, most of the flooded areas stay dry, when the water returns to the river beds or evaporates. Major habitats include patches ( 0.5-5 ha) of semi-deciduous forests (capões) surrounded by grasslands, belts of cerradão or semi-deciduous forests surrounding lagoons (cordilheiras), riparian semi-deciduous forests, and mono-specific forests of woody species such as Tabebuia aurea (paratudal) and Vochysia divergens (cambarazal) (Silva et al., 2000; Araújo and Sazima, 2003). The upper ground (where there are capões and cordilheiras) is at most only a couple of metres above average water level. Rivers and depressions locally known as corixos are lined by riparian forests. In these forest habitats, different species of Ficus and other trees serve as food supply and shelter for frugivores (Teixeira et al., 2009). The uplands surrounding the Pantanal are covered by senso strictu cerrado, cerradão and semi-deciduous forests, which are severely threatened by agriculture and cattle ranching (Alho, 2008; Scariot et al., 2005). Bats were sampled in 35 sites in the Pantanal floodplain and its bordering plateaus, as described below.

\subsubsection{Pantanal sampling sites}

Field work was carried out in 19 sites (Figure 1) in different Pantanal sub-regions and municipalities (see Silva and Abdon, 1998). In the Pantanal sub-region of Pantanal da Nhecolândia eight sites were sampled: Fazenda Nhumirim (18 59' 6.93" S and 56 37' 24.37' W), Fazenda Arara Azul (19 $23^{\prime}$ '41.37' S and 57 1' 43.11" W), Fazenda Guanabara (18 $14^{\prime} 6.5^{\prime \prime} \mathrm{S}$ and $\left.55^{\circ} 45^{\prime} 0.9^{\prime \prime} \mathrm{W}\right)$, Fazenda Campo Neta ( $18^{\circ} 45^{\prime} 38.8^{\prime \prime} \mathrm{S}$ and 56 $6^{\circ} 17^{\prime} 48.3^{\prime}$ 'W), Fazenda Santa Terezinha (19 $22^{\prime} 38.5^{\prime \prime} \mathrm{S}$ and $56^{\circ} 3^{\prime} 20.5^{\prime}$ ' W),

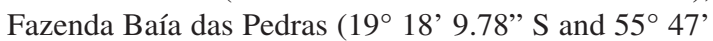

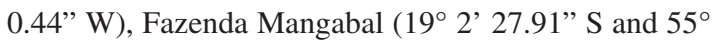
49' 43.97' W), and Fazenda Barra Mansa (19³6'0.94" S and $56^{\circ} 4$ ' $\left.36.31^{\prime \prime} \mathrm{W}\right)$. In the sub-region of Pantanal de Aquidauana seven sites were sampled: Fazenda Conquista (19 18' 15.54" S and 55 14' 40.38' W), Fazenda Santa

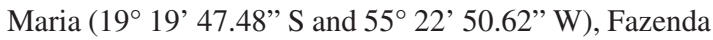

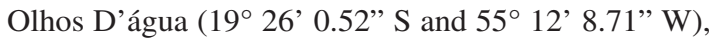

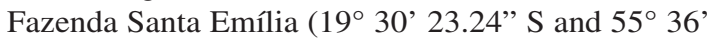
46.10" W), Estância Caiman (19 $57^{\circ}$ '56' $\mathrm{S}$ and 56 $16^{\circ}$ ' $37^{\prime}$ ' W), Fazenda Guaicurus (20 4' 49.96' $\mathrm{S}$ and $56^{\circ} 28^{\prime}$

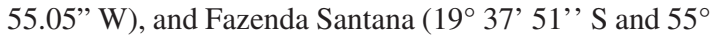
40' 36' ' W). In the sub-region of Pantanal do Miranda three sites were sampled: Fazenda São Bento (19³3' 


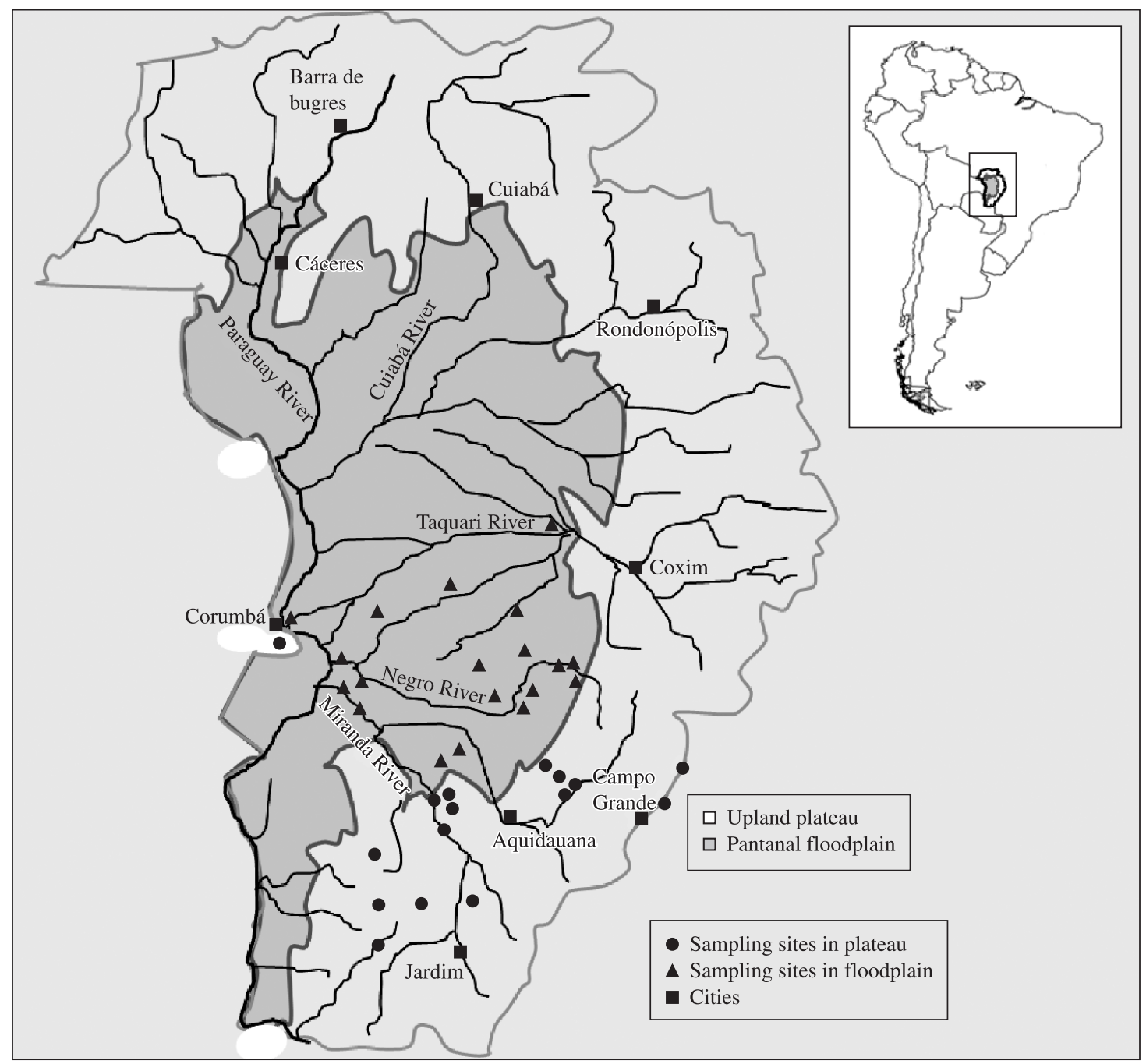

Figure 1. Sampling sites in the Pantanal floodplain (triangles) and in the neighbouring Cerrado upland plateaus (black circles), and cities (grey circles) in Mato Grosso do Sul, Brazil.

40.35" S and 57 1' 29.44" W), Fazenda Santa Clara $\left(19^{\circ} 27^{\prime} 44.10^{\prime \prime} \mathrm{S}\right.$ and $\left.57^{\circ} 4^{\prime} 30.39^{\prime \prime} \mathrm{W}\right)$, and Fazenda Sagrado (19 $25^{\prime} 56.30^{\prime \prime} \mathrm{S}$ and $57^{\circ} 1^{\prime}$ ' 40.81' W). In the sub-region of Pantanal do Paraguai there was one site:

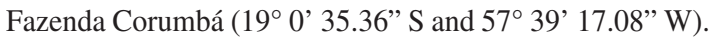

\subsubsection{Upland plateau sampling sites}

Samplings comprised 16 sites in the plateau (Figure 1). In the Maracaju uplands there were six sites: Fazenda Furnas D'água (20 9' $29.38^{\prime}$ ' S and $55^{\circ} 24^{\prime} 16.02^{\prime \prime} \mathrm{W}$ ), Distrito de Camisão (20 $17^{\prime} 11.28^{\prime \prime} \mathrm{S}$ and $\left.55^{\circ} 23^{\prime} 2.07^{\prime \prime} \mathrm{W}\right)$, Distrito de Piraputanga (20 $16^{\circ} 38.03^{\prime \prime} \mathrm{S}$ and $55^{\circ} 18^{\prime}$ $\left.18.54^{\prime \prime} \mathrm{W}\right)$, Fazenda Vista Alegre (20 5' 55.13" S and $\left.54^{\circ} 27^{\prime} 26.67^{\prime \prime} \mathrm{W}\right)$, Município de Campo Grande (20 $27^{\circ}$ ' 4.58" S and 54 36' 57.38" W), Fazenda Taboco (20 3' $36^{\prime \prime} \mathrm{S}$ and $55^{\circ} 36^{\prime} 20^{\prime \prime} \mathrm{W}$ ). In the Bodoquena uplands there were nine sites: Fazenda Campina Grande (20 21' 22.32"
S and $56^{\circ} 22^{\prime} 25.90^{\prime \prime} \mathrm{W}$ ), Fazenda Dona Benedita (20 $20^{\circ}$ $44.78^{\prime \prime} \mathrm{S}$ and $\left.56^{\circ} 26^{\prime} 13.12^{\prime \prime} \mathrm{W}\right)$, Fazenda São Cristóvão $\left(20^{\circ} 20^{\prime} 16.93^{\prime \prime} \mathrm{S}\right.$ and $\left.56^{\circ} 22^{\prime} 55.48^{\prime \prime} \mathrm{W}\right)$, Fazenda São Vicente ( $20^{\circ} 31^{\prime} 25.37^{\prime \prime} \mathrm{S}$ and $\left.56^{\circ} 24^{\prime} 56.63^{\prime \prime} \mathrm{W}\right)$, Fazenda Santa Tereza $\left(21^{\circ} 5^{\prime} 14.27^{\prime \prime} \mathrm{S}\right.$ and $\left.56^{\circ} 3^{\prime} 10.63^{\prime \prime} \mathrm{W}\right)$,

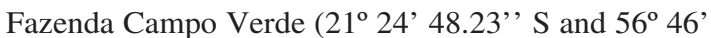
$32.12^{\prime \prime} \mathrm{W}$ ), Fazenda Harmonia ( $21^{\circ} 7$ ' $39.31^{\prime \prime} \mathrm{S}$ and $56^{\circ}$ $45^{\prime} 42.04$ " W), Fazenda Rancho Branco (20 41' 17.62" S and $56^{\circ} 46^{\prime} 42.40^{\prime \prime} \mathrm{W}$ ), Bonito (21 $7^{\circ} 38.46^{\prime \prime} \mathrm{S}$ and $56^{\circ}$ $\left.29^{\prime} 13.68^{\prime \prime} \mathrm{W}\right)$. In the Maciço do Urucum uplands there was one site $\left(19^{\circ} 18^{\prime} 52.42^{\prime \prime} \mathrm{S}\right.$ and $\left.57^{\circ} 36^{\prime} 12.19^{\prime \prime} \mathrm{W}\right)$.

\subsection{Samplings and analyses}

This study relies on the bat scientific collection organised by Dr. Valdir Antônio Taddei at Universidade Anhanguera - Uniderp, Campo Grande, MS, between 1994 and 2006, with 4,239 bat specimens collected through 
different procedures, predominantly straightforward mistnet surveys, and on the Projeto Morcegos do Pantanal databank at UFMS, Campo Grande, MS, with 4,798 bat entries through mist-net captures between 1998 and 2007. Surveys covered different hydrological seasons of the Pantanal and its surroundings in different habitats, near fruiting trees, bat shelters, or forest canopies. Total capture effort was about 290,000 h.m² (time in which nets were kept open multiplied by the area of the nets), distributed throughout 376 nights, with four to 12 nets of variable sizes open per night. Biometrical data were obtained and voucher specimens were prepared for identification, which followed the criteria established by Vizotto and Taddei (1973), Taddei (1983), Anderson (1997), Lopez-González et al. (2001), Gregorin and Taddei (2002), Vicente et al. (2005), and Reis et al. (2006, 2007).

\section{Results and Discussion}

\subsection{Bat fauna in south Pantanal and surrounding uplands}

In all 35 sites 9,037 individuals belonging to 56 species, 36 genera and six families were recorded (Table 1). This number of species represents $34 \%$ of the whole richness of bats in Brazil, including the Amazon, annotated by Reis et al. (2006, 2007); it reaches $62 \%$ of the total richness reported for the entire Upper Paraguay River Basin ( $\mathrm{n}=90$ bat species), including the northern area in Mato Grosso, Brazil, and the Bolivian and Paraguayan areas (Tomas et al., 2009). In the floodplain sites, 6,292 individuals of 46 species were captured, a number which reaches $64 \%$ of the bat species already registered in the whole Pantanal floodplain (Tomas et al., 2009; Alho et al., 2003); in the upland sites surrounding the Pantanal 2,745 individuals of 44 species were recorded, representing $65 \%$ of the bat species already reported to occur along the entire Pantanal borders (Tomas et al., 2009). The large number of captures and the cumulative curve of species captured (Figure 2), throughout a relatively long period of time dedicated to survey (1994-2007), indicate that overall species richness was well sampled and that this is a reliable representation of bat diversity in the focal region. In addition, five species found here - Diphylla ecaudata, Mimon bennettii, Trachops cirrhosus, Uroderma magnirostrum, and Molossus pretiosus - were still not reported for Mato Grosso do Sul (Cáceres et al., 2008), increasing to 66 the number of bat species registered in this state.

The richest and most abundant families in our 35 study sites were Phyllostomidae (30 species and 6,228 individuals) and Molossidae (12 species and 1,071 individuals) (Table 1), corresponding to $34 \%$ and $46 \%$ of the Brazilian species in these two families respectively (Gregorin and Taddei, 2002; Reis et al., 2006, 2007). Richness of molossid bats (all insectivorous) in the floodplain $(\mathrm{n}=11)$ was almost twice that in the upland plateaus $(n=6)$, largely contributing to the high number of insectivorous species exclusively found in the floodplain rather than in plateaus (Figure 3).
Otherwise, the number of phyllostomid species in plateaus $(n=27)$ was slightly higher than in the floodplain $(n=23)$, contributing to the increased number of exclusively frugivorous species in the plateaus (Figure 3). Although phyllostomids were richer in plateaus, the subfamily Phyllostominae presented more species in the floodplain; and it included all the insectivorous bats among phyllostomid species. Therefore, insectivory appears to be a trait which favours the occurrence of bat species in the floodplain. Indeed, even the frugivorous phyllostomids feed on insects proportionally more in the Pantanal floodplain than in its bordering plateaus or elsewhere (Munin, 2008; Teixeira et al., 2009). Diets toward insectivory might be partially explained because insects are available throughout the year, and massively during several months, whereas bat fruit sources are markedly seasonal and poor in the Pantanal floodplain (Munin, 2008; Teixeira et al., 2009).

Artibeus planirostris ( $\mathrm{n}=3,101$ individuals) was by far the most dominant bat species throughout the entire focal region (Figure 4), showing one order of magnitude more captures than the next nine highly common species - Myotis nigricans $(\mathrm{n}=762)$, Molossus molossus $(\mathrm{n}=692)$, Noctilio albiventris $(\mathrm{n}=681)$, Platyrrhinus lineatus $(\mathrm{n}=633)$, Sturnira lilium $(\mathrm{n}=461)$, Carollia perspicillata $(\mathrm{n}=451)$, Glossophaga soricina $(\mathrm{n}=436)$, Artibeus lituratus $(\mathrm{n}=320)$, and Desmodus rotundus $(\mathrm{n}=281)$. Such strong dominance of $A$. planirostris has been also reported in other local surveys in the Pantanal floodplain and in its neighbouring upland regions (Camargo, 2003; Camargo et al., 2009; Cunha et al., 2009; Teixeira et al., 2009). Although the dominance by A. planirostris occurred in both regions, in the Pantanal floodplain there were three insectivorous non-phyllostomid species (Myotis nigricans, Noctilio albiventris, and Molossus molossus) among the most common bats, contrasting with the upland plateaus where the commonest species were all frugivorous phyllostomids (Figure 4). The frugivorous C. perspicillata was the second most abundant species in the uplands, but it was not one of the top ten species in the floodplain (Figure 4). Thus, the relative abundance of insectivorous bats appears to be higher in the floodplain than in the uplands, probably for the same reasons which explain the exceptionally high richness of insectivores as discussed above. Calculated values for the Shannon index of diversity were similar between the Pantanal floodplain $\left(H^{\prime}=2.3\right)$ and its neighbouring uplands $\left(H^{\prime}=2.5\right)$. Assembling all the 35 sampling sites, diversity was found to be $H^{\prime}=2.5$. These values are higher than those $\left(H^{\prime}=1.5\right.$ to 1.8$)$ found in short-term surveys in the Bodoquena region (Camargo et al., 2009; Cunha et al., 2009), and closer to values ( $H^{\prime}=1.8$ to 2.3 ) found for different areas in the Atlantic forest in southeastern Brazil (Pedro and Taddei, 1997; Esbérard, 2003).

In pockets of cerrado habitats the most abundant species are Artibeus planirostris $(\mathrm{n}=431)$, Noctilio albiventris $(\mathrm{n}=381)$ and Molossus molossus $(\mathrm{n}=362)$. In fragments of semi-deciduous and deciduous forest on plateaus on the outskirts of the Pantanal the common species are: Myotis nigricans $(\mathrm{n}=489)$, Noctilio albiventris $(\mathrm{n}=168)$ 
Table 1. Number of surveyed individuals from 1995 to 2007 and feeding niche of 56 bat species in the Pantanal floodplain and its surrounding upland plateaus, Mato Grosso do Sul, Brazil.

\begin{tabular}{|c|c|c|c|c|}
\hline \multirow{2}{*}{ Family / Species } & \multicolumn{3}{|c|}{ Number of individuals } & \multirow{2}{*}{ Feeding nich } \\
\hline & Flood plain & Plateau & $\Sigma$ & \\
\hline Phyllostomidae & 3856 & 2372 & 6228 & \\
\hline Artibeus planirostris (Spix, 1823) & 2335 & 766 & 3101 & Frugivore \\
\hline Platyrrhinus lineatus (E. Geoffroy, 1810) & 382 & 251 & 633 & Frugivore \\
\hline Sturnira lilium (E.Geoffroy, 1810) & 199 & 262 & 461 & Frugivore \\
\hline Carollia perspicillata (Linnaeus, 1758) & 87 & 364 & 451 & Frugivore \\
\hline Glossophaga soricina (Pallas, 1766) & 225 & 211 & 436 & Nectarivore \\
\hline Artibeus lituratus (Olfers, 1818) & 177 & 143 & 320 & Frugivore \\
\hline Desmodus rotundus (E. Geoffroy, 1810) & 190 & 91 & 281 & Sanguivore \\
\hline Anoura geoffroyi Gray, 1838 & 0 & 124 & 124 & Nectarivore \\
\hline Lophostoma silvicolum d'Orbigny, 1836 & 84 & 13 & 97 & Insectivore \\
\hline Phyllostomus hastatus (Pallas, 1767) & 59 & 30 & 89 & Frugivore \\
\hline Anoura caudifer (E. Geoffroy, 1818) & 1 & 57 & 58 & Nectarivore \\
\hline Phyllostomus discolor Wagner, 1843 & 39 & 7 & 46 & Frugivore \\
\hline Chrotopterus auritus (Peters, 1856) & 21 & 12 & 33 & Carnivore \\
\hline Platyrrhinus helleri (Peters, 1866) & 8 & 10 & 18 & Frugivore \\
\hline Diaemus youngi (Jentink, 1893) & 16 & 0 & 16 & Sanguivore \\
\hline Lophostoma brasiliense Peters, 1866 & 9 & 2 & 11 & Insectivore \\
\hline Mimon bennettii (Gray, 1838) & 7 & 4 & 11 & Insectivore \\
\hline Vampyressa pusilla (Wagner, 1843) & 2 & 5 & 7 & Frugivore \\
\hline Chiroderma villosum Peters, 1860 & 5 & 1 & 6 & Frugivore \\
\hline Chiroderma doriae Thomas, 1891 & 2 & 3 & 5 & Frugivore \\
\hline Mimon crenulatum (E. Geoffroy, 1810) & 5 & 0 & 5 & Insectivore \\
\hline Tonatia bidens (Spix, 1823) & 1 & 4 & 5 & Insectivore \\
\hline Micronycteris minuta (Gervais, 1856) & 1 & 3 & 4 & Insectivore \\
\hline Phylloderma stenops Peters, 1865 & 0 & 3 & 3 & Frugivore \\
\hline Uroderma magnirostrum Davis, 1868 & 0 & 2 & 2 & Frugivore \\
\hline Diphylla ecaudata Spix, 1823 & 0 & 1 & 1 & Sanguivore \\
\hline Macrophyllum macrophyllum Schinz, 1821 & 0 & 1 & 1 & Insectivore \\
\hline Pygoderma bilabiatum (Wagner, 1843) & 0 & 1 & 1 & Frugivore \\
\hline Trachops cirrhosus (Spix, 1823) & 0 & 1 & 1 & Carnivore \\
\hline Vampyrodes caraccioli (Thomas, 1889) & 1 & 0 & 1 & Frugivore \\
\hline Molossidae & 833 & 238 & 1071 & \\
\hline Molossus molossus (Pallas, 1766) & 602 & 90 & 692 & Insectivore \\
\hline Molossus rufus E.Geoffroy Saint-Hilaire, 1805 & 4 & 84 & 88 & Insectivore \\
\hline Molossops temminckii (Burmeister, 1854) & 50 & 21 & 71 & Insectivore \\
\hline Cynomops abrasus (Temminck, 1827) & 42 & 0 & 42 & Insectivore \\
\hline Eumops auripendulus (Shaw, 1800) & 34 & 6 & 40 & Insectivore \\
\hline Molossus pretiosus Miller, 1902 & 39 & 0 & 39 & Insectivore \\
\hline Nyctinomops macrotis (Gray, 1840) & 0 & 28 & 28 & Insectivore \\
\hline Promops centralis Thomas, 1915 & 26 & 0 & 26 & Insectivore \\
\hline Cynomops planirostris (Peters, 1865) & 21 & 0 & 21 & Insectivore \\
\hline Eumops glaucinus (Wagner, 1843) & 11 & 0 & 11 & Insectivore \\
\hline Nyctinomops laticaudatus (E.Geoffroy Saint-Hilaire, 1805 & 1 & 9 & 10 & Insectivore \\
\hline Promops nasutus (Spix, 1823) & 3 & 0 & 3 & Insectivore \\
\hline
\end{tabular}


Table 1. Continued...

\begin{tabular}{|c|c|c|c|c|}
\hline \multirow{2}{*}{ Family / Species } & \multicolumn{3}{|c|}{ Number of individuals } & \multirow{2}{*}{ Feeding niche } \\
\hline & Flood plain & Plateau & $\sum$ & \\
\hline Vespertilionidae & 895 & 92 & 987 & \\
\hline Myotis nigricans (Schinz, 1821) & 712 & 50 & 762 & Insectivore \\
\hline Myotis albescens (E. Geoffroy, 1906) & 109 & 7 & 116 & Insectivore \\
\hline Eptesicus furinalis (d'Orbigny and Gervais, 1847) & 15 & 21 & 36 & Insectivore \\
\hline Lasiurus ega (Gervais, 1856) & 22 & 1 & 23 & Insectivore \\
\hline Myotis riparius Handley, 1960 & 15 & 4 & 19 & Insectivore \\
\hline Myotis simus (Thomas, 1901) & 18 & 0 & 18 & Insectivore \\
\hline Lasiurus blossevillii (Lesson and Garnot, 1826) & 0 & 7 & 7 & Insectivore \\
\hline Eptesicus brasiliensis (Desmarest, 1819) & 3 & 1 & 4 & Insectivore \\
\hline Lasiurus cinereus (Beauvois, 1796) & 1 & 1 & 2 & Insectivore \\
\hline Noctilionidae & 690 & 41 & 731 & \\
\hline Noctilio albiventris Desmarest, 1818 & 641 & 40 & 681 & Insectivore \\
\hline Noctilio leporinus (Linnaeus, 1758) & 49 & 1 & 50 & Piscivore \\
\hline Emballonuridae & 18 & 0 & 18 & \\
\hline Rynchonycteris naso (Wied-Neuwied, 1820) & 13 & 0 & 13 & Insectivore \\
\hline Peropteryx macrotis (Wagner, 1843) & 5 & 0 & 5 & Insectivore \\
\hline Mormoopidae & 0 & 2 & 2 & \\
\hline Pteronotus parnellii (Gray, 1843) & 0 & 2 & 2 & Insectivore \\
\hline$\sum$ & 6292 & 2745 & 9037 & \\
\hline
\end{tabular}

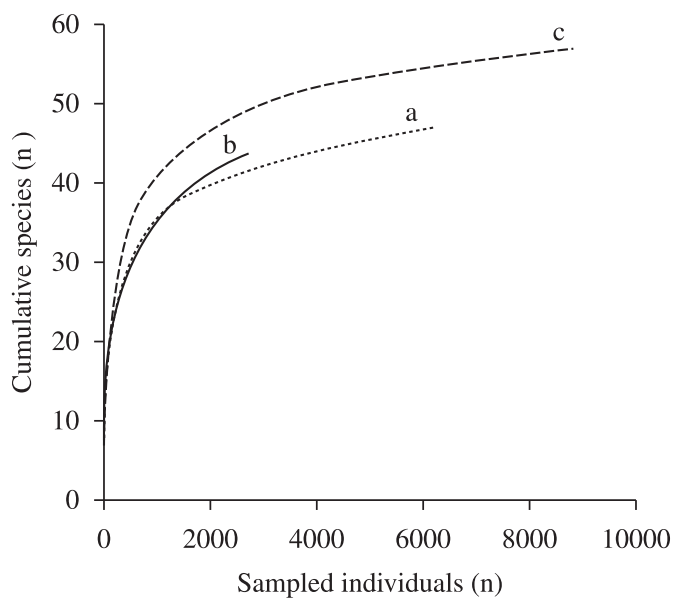

Figure 2. Rarefaction curves for bats sampled in 19 sites in the Pantanal floodplain (a), and in 16 sites in the surrounding upland plateaus (b), in Mato Grosso do Sul, Brazil. The upper curve refers to all these 35 sites assembled (c).

and Molossus molossus $(\mathrm{n}=155)$. In disturbed areas, near the houses of cattle ranchers, the common species are: Carollia perspicillata $(\mathrm{n}=129)$, Molossus molossus $(\mathrm{n}=125)$ and Artibeus planirostris $(\mathrm{n}=97)$. Figure 5 shows the distribution of the species within three major kinds of

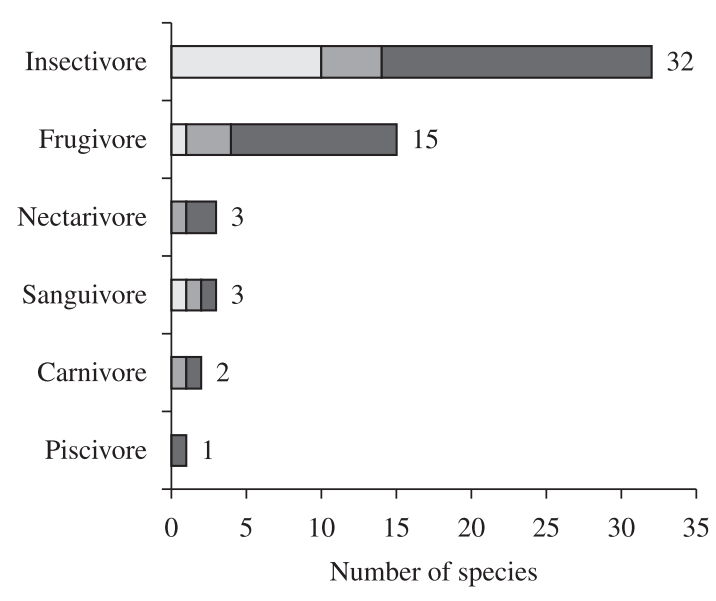

Figure 3. Richness of bats according to feeding niche, based on 9,037 individuals examined belonging to 56 species, in the Pantanal floodplain and in its neighbouring upland plateaus, Mato Grosso do Sul, Brazil. Light grey bars indicate species exclusive to the floodplain, grey bars species only found in plateau, and dark grey bars those occurring in both floodplain and plateau.

habitats: Cerrado, disturbed habitats and semi-deciduous forest of plateaus. On the other hand, 24 rare species were detected, such as Chiroderma doriae, Chrotopterus auritus, and Artibeus lituratus (Table 1). Chiroderma doriae is a species which requires habitat integrity and so 


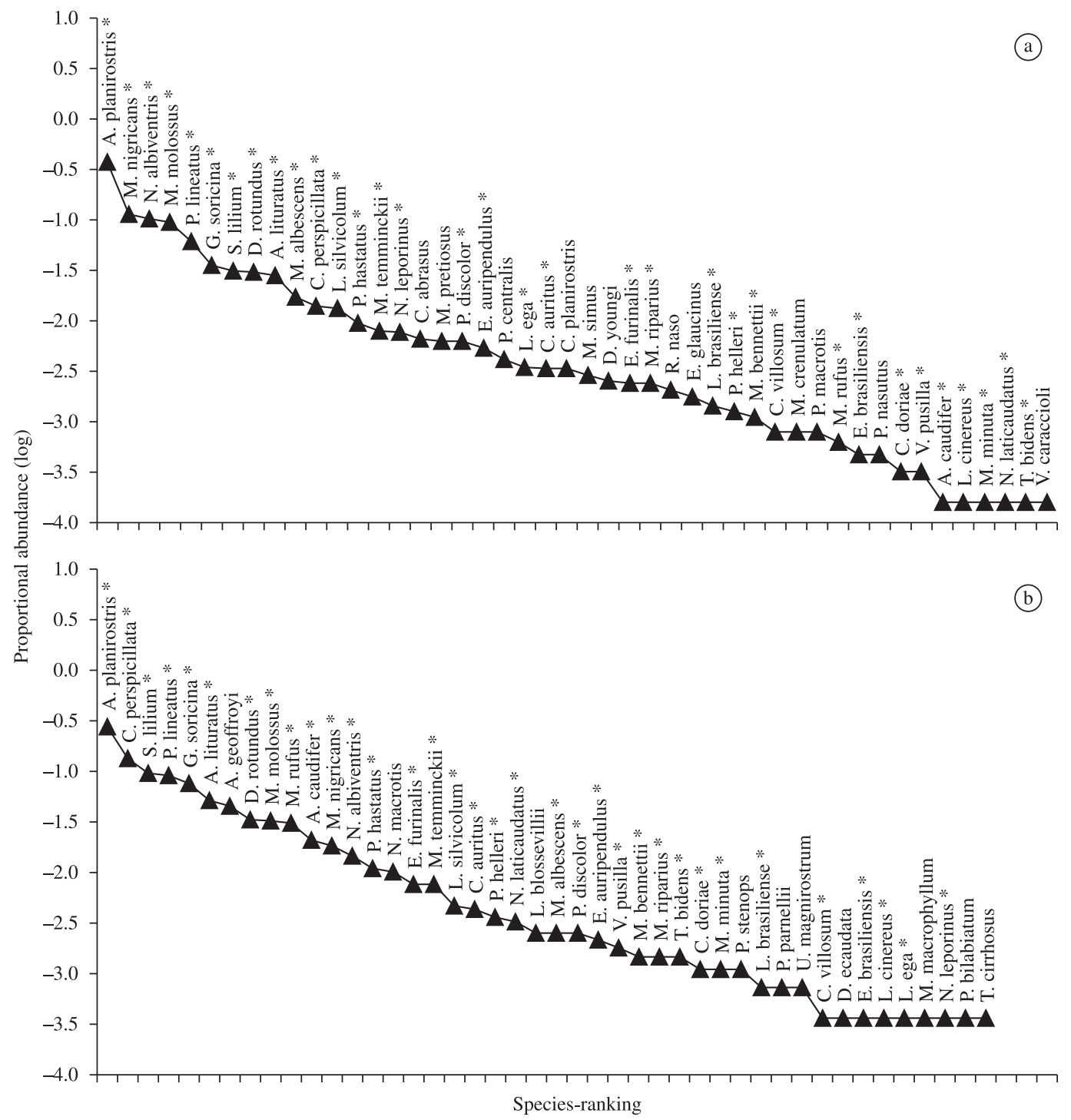

Figure 4. Rank abundance distribution of 56 species of bats in a) the Pantanal floodplain and b) its surrounding upland plateaus in Mato Grosso do Sul, Brazil. Asterisks indicate species which were recorded in both the floodplain and uplands.

is sensitive to disturbance. Some authors (Bergallo et al., 2000) consider this species as threatened by extinction, but it is not listed in the "Livro Vermelho da Fauna Brasileira Ameaçada de Extinção [The Red Book of Brazilian Fauna under Threat of Extinction]", published by the Ministry for the Environment (Ministério do Meio Ambiente) in 2008. No species found in our survey for the Pantanal is officially listed as threatened. Chrotopterus auritus is a large carnivore/insectivore, preying on small mammals, birds and insects, which is very sensitive to environmental disturbance, requiring good forest habitats and shelter in caves. Artibeus lituratus was recorded at only $1.5 \%$ in our study, but it is a good coloniser of disturbed habitat, besides living in low densities. The survey conducted in the region of Aporé-Sucuriú, northern Mato Grosso do Sul, revealed that the most caught family was Phyllostomidae, represented by Glossophaga soricina and Artibeus lituratus; and some rare species such as Lophostoma brasiliense, Lonchophylla mordax and Lionycteris spurrelli (Bordignon, 2006).

To analyse possible grouping of species or assemblages in the three major habitats, we performed a non-metric multi-dimensional scaling analysis taking the frequencies of species distribution, and found that the grouping composed of Myotis albescens, Molossops temminckii, Sturnira lilium, Phyllostomus hastatus, Desmodus rotundus, Glossophaga soricina, Carollia perspicillata, Platyrrhinus lineatus, Molossus molossus, Artibeus planirostris and Noctilio albiventris occurs in the three major habitats: cerrado, semi-deciduous forest and disturbed habitats (with $82 \%$ of similarity). 


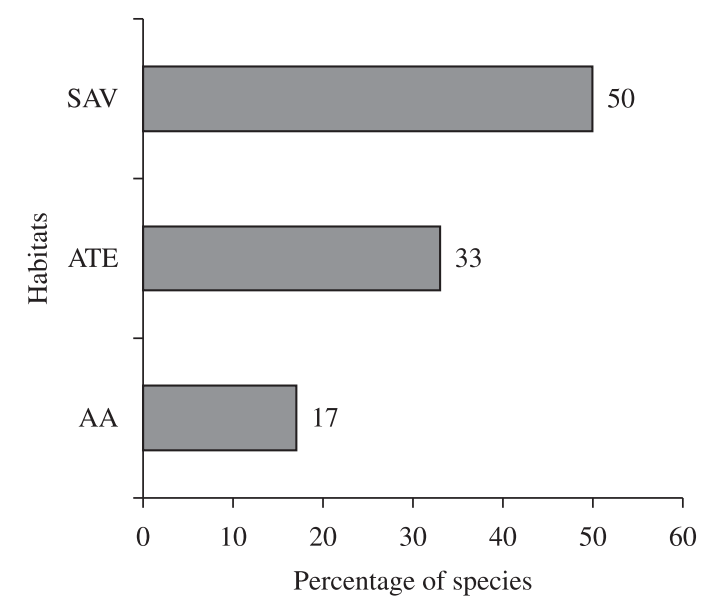

Figure 5. Distribution of the bat species in three major habitats in Mato Grosso do Sul, Brazil. SAV: savanna or Cerrado; AA: disturbed areas near ranches and other human occupation; and ATE: the ecotone zone between the floodplain and the upland "planalto", covered by semi-deciduous forest.

\subsection{Bat species as bio-indicator}

The Pantanal is undoubtedly an important domain and therefore deserves comprehensive ecosystem studies. Our present information on bat species richness and assemblages, considering such abundant sampling data, contributes to making a more general interpretation of species magnitude for conservation purposes. Bat species, for example, can serve as indicators for habitat quality. Natural habitats of the Pantanal have been disrupted by non-sustainable practices of socio-economic development, mainly by conversion of natural vegetation to pastures for cattle ranching and agriculture (Alho, 2008). Farms have been established in the floodplain and in its surrounding uplands, where much of the natural vegetation has been converted to soybean plantations or to other human activities. Studies concluded that $17 \%$ of the Pantanal has been deforested through the use of fire (mainly cerrado patches or "capões de cerrado"), with an annual rate of deforestation of $2.3 \%$; and $63 \%$ of the natural vegetation cover of the surrounding plateaus in the Planalto (savanna woodland and semi-deciduous forests) has been destroyed (Harris et al., 2005). Deforestation between 1976 and 2008 in the Pantanal floodplain increased 26.5 times (12.14\%), compared to $40.97 \%$ of deforestation within the Upper Paraguay basin (Silva et al., 2010).

In pastures continuously used for cattle ranching, the dominance of A. planirostris in the bat assemblages is higher than in areas used intermittently by cattle (C. Santos, unpublished data), indicating that cattle ranching may cause a reduction in bat diversity. In addition, fire events seem to promote changes in bat species composition. Artibeus planirostris has been found to be the most abundant bat in both burned and unburned sites in the floodplain; however, after fire, the insectivorous phyllostomine bats increase in abundance, whereas the abundance of frugivorous stenodermatines and nectarivorous glossophagines decreases (C. Santos, unpublished data).

Our data show a high number of Phyllostomidae, which may represent a good indicator for low levels of habitat disturbance (Pedro at al., 1995; Pedro, 1998; Medellín et al., 2000). This family is well diversified in number of species and in feeding habits. The high number of frugivore species in the family implies that the habitats support a high number of fruit-bearing trees (see Pott and Pott, 1994). In addition, the high primary production favours an increased abundance of arthropods, which supports the guild of insectivore bats. The abundance of frugivore species reflects the importance of this guild for the Pantanal bat assemblages. In addition, bats play an important role in regulating the Pantanal ecosystem as seed dispersers, pollinators and regulators of insect populations (Gonçalves et al., 2007; Munin, 2008; Teixeira et al., 2009). Given that some bat species or bat assemblages require pristine habitat conditions while others are opportunistic, taking advantage of some disturbance, the group should be more studied as an indicator of levels of change in the natural environment. Drastic human alteration in natural habitats may result in simplifying bat diversity and assemblage, since those species which require more specific items in feeding strategy tend to disappear, while those with a wide spectrum of feeding habits, such as insectivore-omnivore and frugivore-omnivore, are generally less affected by environmental changes.

Effects of forest fragmentation on frugivore and nectarivore species have been pointed out in French Guiana (Cossons, 1999). The role of frugivorous bats has been emphasised in tropical forest succession (Muscarella and Flemming, 2007). Overall, Phyllostomid bats have been identified as indicators of habitat disruption in the Neotropics (Fenton et al., 1992). Work conducted in forest habitats of Paraguay has shown that abundance was highest for Artibeus lituratus in deforested landscapes and for Chrotopterus auritus in forested habitats; in contrast, Artibeus fimbriatus, Carollia perspicillata, Glossophaga soricina, Platyrrhinus lineatus, Pygoderma bilabiatum, and Sturnira lilium attained highest abundance in moderately fragmented forest landscapes. Forest cover, patch size, and patch density frequently were associated with abundance of species (Gorresen and Willig, 2004).

Therefore, our data indicate that bat species richness and assemblages in the Pantanal and its surrounding habitats are still well preserved, and it is hoped that these findings may be useful for constructive lines of biodiversity conservation and management in this important wetland ecosystem.

Acknowledgements - This study was partially supported by the Fundação de Apoio ao Desenvolvimento do Ensino, Ciência e Tecnologia do Estado de Mato Grosso do Sul (FUNDECT) grants to Dr. Cleber Alho (Termo de Outorga n. ${ }^{\circ}$ 0133/06), to E. Fischer (Termos de Outorga n. ${ }^{\circ}$ 131/04, 079/06, and 073/08), and a doctoral grant to C. Santos (Process n. ${ }^{\circ} 41 / 100.271 / 2006$ ); additional funds and field work support 
were provided by Earthwatch Institute, Fundação O Boticário de Proteção à Natureza, Conservation International, Wildlife Conservation Society, and Fundação Neotrópica do Brasil. Some data of this paper are part of the Master's dissertation of Larissa F. Oliveira-Pissini, working under the academic and scientific advice of Professor Cleber Alho at Uniderp. We thank Dr. Silvio Favero - Coordinator of the environmental Master's program of Uniderp - for his support. We would like to emphasise the enormous value of the bat scientific collection constructed by Dr. Valdir Antonio Taddei, and in his honour in memoriam - we dedicate this work. Celina Alho and Susan Casement reviewed the manuscript.

\section{References}

AGUIRRE, LF., 2002. Structure of a Neotropical savanna bat community. Journal of Mammalogy, vol. 83, no. 3, p. 775-784.

ALHO, CJR., 2005. The Pantanal. In FRASER, LH. and KEDDY, PA., Org. The World's Largest Wetlands - Ecology and Conservation. New York, USA: Cambridge University Press, p. 203-271.

-, 2008. Biodiversity of the Pantanal: response to seasonal flooding regime ant to environmental degradation. Brazilian Journal of Biology, vol. 68, no. 4, p. 957-966. Suppl.

ALHO, CJR., STRUSSMANN, C., VOLPE, M., SONODA, F., MARQUES, AAB., SCHNEIDER, M., SANTOS JUNIOR, TS. and MARQUES, SR., 2003. Conservação da biodiversidade da Bacia do Alto Paraguai. Campo Grande, MS: Editora UNIDERP. 466 p.

ANDERSON, S., 1997. Mammals of Bolivia: taxonomy and distribution. Bulletin of the American Museum of Natural History, no. $231,652 \mathrm{p}$.

ARAÚJO, AC. and SAZIMA, M., 2003. The assemblage of flowers visited by hummingbirds in the "capões" of southern Pantanal, Mato Grosso do Sul, Brazil. Flora, vol. 198, p. 427-435.

BERGALLO, HG., GEISE, L., BONVICINO, CR., CERQUEIRA, R., D'ANDREA, PS., ESBÉRARD, CE., FERNANDEZ, FAS., GRELLE, CE., PERACCHI, A., SICILLIANO, S. and VAZ, SM., 2000. Mamíferos. In BERGALLO, MV., ROCHA, CFD., ALVES, MAS., SLUYS, MV., Org. A fauna ameaçada de extinção do Estado do Rio de Janeiro. Rio de Janeiro, Ed. UERJ. p. 125-135.

BORDIGNON, MO., 2006. Diversidade de morcegos (Mammalia, Chiroptera) do Complexo Aporé-Sucuriú, Mato Grosso do Sul, Brasil. Revista Brasileira de Zoologia, vol. 23, no. 4, p. 1002-1009.

CÁCERES, NC., CARMIGNOTTO, AP., FISCHER, E. and SANTOS, CF., 2008. Mammals from Mato Grosso do Sul, Brazil. Check List, vol. 4, no. 3, p. 321-335.

CAMARGO, G. and FISCHER, E., 2005. Primeiro registro do morcego Mimon crenulatum (Phyllostomidae) no Pantanal, sudoeste do Brasil. Biota Neotropica, vol. 5, no. 1. Available from: <http:// www.biotaneotropica.org.br/v5n1/pt/abstract?short-communication +BN00705012005>

CAMARGO, G., 2003. Riqueza e diversidade de morcegos no Pantanal do Miranda-Abobral, Mato Grosso do Sul. Campo Grande: Universidade Federal de Mato Grosso do Sul. 51 p. Dissertação de mestrado em ecologia e conservação.

CAMARGO, G., FISCHER, E., GONÇALVES, F., FERNANDES, G. and FERREIRA, S., 2009. Morcegos do Parque Nacional da Serra da Bodoquena, Mato Grosso do Sul, Brasil. Chiroptera Neotropical, vol. 15, no. 1, p. 417-424.
COSSONS, JF., PONS, JM. and MASSON, B., 1999. Effects of forest fragmentation on frugivorous and nectarivorous bats in French Guiana. Journal of Tropical Ecology, vol. 15, no. 4, p. 515-534.

CUNHA, NL., FISCHER, E., CARVALHO, LFAC. and SANTOS, CF., 2009. Bats of Buraco das Araras natural reserve, southwestern Brazil. Biota Neotropica, vol. 9, no. 4. Available from: <http://www. biotaneotropica.org.br/v9n4/pt/abstract?inventory+bn02909042009>.

DROBNER, U., BIBBY J., SMITH, B. and WILSON, JB., 1998. The relation between community biomass and evenness: what does theory predict, and can these predictions be tested. Oikos, vol. 82 , p. 295-302.

ESBÉRARD, CEL., 2003. Diversidade de morcegos em uma área de Mata Atlântica regenerada no sudeste do Brasil (Mammalia: Chiroptera). Revista Brasileira de Zoociências, vol. 5, p. 189-204.

FALCÃO, FC., REBÊLO, VF. and TALAMONI, SA., 2003. Structure of a bat assemblage (Mammalia, Chiroptera) in Serra do Caraça Reserve, South-east Brazil. Revista Brasileira de Zoologia, vol. 20, no. 2, p. 347-350.

FENTON, MB., ACHARYAL, L., AUDET, D., HICKEY, MBC., MERRIMAN, C., OBRIST, MK., SYME, DM. and ADKINS, B., 1992. Phyllostomid bats (Chiroptera:Phyllostomidae) as indicators of habitat disruption in the Neotropics. Biotropica, vol. 24 , p. $440-446$.

GONÇALVES, F., MUNIN, R., COSTA, P. and FISCHER, E., 2007. Feeding habits of Noctilio albiventris (Noctilionidae) bats in the Pantanal, Brazil. Acta Chiropterologica, vol. 9, no. 2, p. 535-546.

GORRESEN, PM. and WILLIG, MR., 2004. Landscape responses of bats to habitat fragmentation in Atlantic Forest of Paraguay. Journal of Mammalogy, vol. 85, no. 4, p. 688-697.

GREGORIN, R. and TADDEI, VA., 2002. Chave artificial para a identificação de molossídeos brasileiros (Mammalia, Chiroptera). Mastozologia Neotropical, vol. 1, no. 9, p. 13-32.

HARRIS, MB., ARCANGELO, C., PINTO, ECT., CAMARGO, G., RAMOS-NETO, MB. and SILVA, SM., 2005. Estimativas de perda da área natural da Bacia do Alto Paraguai e Pantanal Brasileiro. Campo Grande, MS: Conservation International. Unpublished Technical Report.

KEDDY, PA., FRASER, LH., SOLOMESHCH, AI., JUNK, WJ., CAMPBEL, DR., ARROYO, MTK. and ALHO, CJR., 2009. Wet and wonderful: the word's largest wetlands are conservation priorities. BioScience, vol. 59, no. 1, p. 39-51.

LEITE, A., MENEGHELLI, M. and TADDEI, VA., 2000. Morcegos do Pantanal do Estado do Mato Grosso do Sul. In Anais do II Encontro de Pesquisa e Iniciação Científica da UNIDERP. Campo Grande. p. 129-131.

-, 1998. Morcegos (Chiroptera: Mammalia) dos pantanais de Aquidauana e da Nhecolândia, Mato Grosso do Sul. I. Diversidade de espécies. Ensaios e Ciência, vol. 2, no. 2, p. 167-174.

LONGO, JM., FISCHER, E., CAMARGO, G. and SANTOS, CF., 2007. Occurrence of Vampyressa pusilla Chiroptera, Phyllostomidae) in Southern Pantanal. Biota Neotropica, vol. 7, no. 3. Available from: <http://www.biotaneotropica.org.br/v7n3/ pt/abstract?short-communication+bn02407032007>.

LÓPEZ-GONZÁLEZ, C., PRESLEY, SJ., OWEN, RD. and WILLIG, MR., 2001. Taxonomic status of Myotis (Chiroptera:Vespertilionidae) in Paraguay. Journal of Mammalogy, vol. 1, no. 82, p. 138-160. 
MARINHO-FILHO, J. and SAZIMA, I., 1998. Brazilian bats and conservation biology; a First Survey. In KUNZ, TH. and RACEY, PA., Ed. Bat, biology and conservation. Washington, D.C.: Smithsonian Institution Press. p. 282-294.

MEDELLÍN, RA., EQUÍHUA, M. and AMIN, MA., 2000. Bat diversity and abundance as indicators of disturbance in Neotropical rainforests. Conservation Biologi, vol. 14, p. 1666-1675.

MUNIN, RL., 2008. Utilização e sobreposição de itens alimentares por morcegos filostomídeos no Pantanal da Nhecolândia, Mato Grosso do Sul. Campo Grande: Universidade Federal de Mato Grosso do Sul. 41 p. Dissertação de mestrado em ecologia e conservação.

MUSCARELLA, R. and FLEMMING, TH., 2007. The role of frugivorous bats in tropical forest succession. Biological Reviews, vol. 82 , p. $573-590$.

PATTERSON, BD., WILLIG, MR. and STEVENS, RD., 2001. Tropic strategies, niche partitioning, and patterns of ecological organization. In KUNZ, TH. and FENTON, MB., Ed. Bat ecology. Chicago, Illinois, USA: University of Chicago Press.

PEDRO, WA. and TADDEI, VA., 1997. Taxonomic assemblage of bats from Panga Reserve, southeastern Brazil: abundance patterns and trophic relations in the Phyllostomidae (Chiroptera). Boletim do Museu Biológico Mello Leitão, vol. 6, p. 3-21.

PEDRO, WA., 1998. Diversidade de morcegos em habitas florestais fragmentos do Brasil (Chiroptera; Mammalia). São Carlos: Universidade Federal de São Carlos. 128 p. Tese de doutorado em ecologia e recursos naturais.

PEDRO, WA., GERALDES, MP., LOPES, GG. and ALHO, CJR., 1995. Fragmentação de habitat e a estrutura de uma taxocenose de morcegos em São Paulo (Brasil). Chiroptera Neotropical, vol. 1, no. 1, p. 4-6.

POTT, A. and POTT, VJ., 1994. Plantas do Pantanal. Corumbá: EMBRAPA/CPAP. 320 p.

REIS, NR., PERACCHI, A., PEDRO, WA. and LIMA, IP., Ed., 2007. Morcegos do Brasil. Londrina. 253 p.

-, 2006. Mamíferos do Brasil. Londrina. 437 p.

ROHDE, K., 1992. Latitudinal gradients in species diversity: the search for the primary cause. Oikos, vol. 65, p. 514-527.

SCARIOT, A., SOUSA-SILVA, JC., FELFILI, JM., Ed., 2005. Cerrado: ecologia, biodiversidade e conservação. Brasília: Ministério do Meio Ambiente. 439 p.

SILVA, JSV. and ABDON, MM., 1998. Delimitação do Pantanal brasileiro e suas sub-regiões. Pesquisa Agropecuária Brasileira, vol. 33, no. especial, p. 1703-1711.

SILVA, JSV., ABDON, MM., MORAES, JA., 2010. Desmatamento na bacia do Alto Paraguai no Brasil. In Anais $3^{\circ}$ Simpósio de Geotecnologias no Pantanal. Cáceres, MT, 16-20 de outubro 2010. Embrapa Informática Agropecuária/INPE, p. 459-467.

SILVA, MP., MAURO, R., MOURÃO, G. and COUTINHO, M., 2000. Distribuição e quantificação de classes de vegetação do Pantanal através de levantamento aéreo. Revista Brasileira de Botânica, vol. 23, no. 2, p. 143-152.

STEVENS, RD. and WILLIG, MR., 2002. Geographical ecology at the community level: perspectives on the diversity of New World bats. Ecology, vol. 83, no. 2, p. 543-560.

TADDEI, VA., 1983. Morcegos - Algumas considerações sistemáticas e biológicas. Campinas: Coordenadoria de Assistência Técnica Integral. $31 \mathrm{p}$.

TADDEI, VA., LEITE, AP., VICENTE, EC., SOUZA, HA. and MENEGHELLI, M., 2000. Morcegos da Estância Caiman, Município de Miranda, Estado do Mato Grosso do Sul. In Anais do II Encontro de Pesquisa de Iniciação Científica da UNIDERP. Campo Grande. p. 128-129.

TADDEI, VA., PULCHÉRIO, AL. and MENEGHELLI, M., 2001. Morcegos de áreas antropizadas da Estância Caiman, Município de Miranda, Estado do Mato Grosso do Sul. In Anais do XII Encontro de Biólogos do CRB-1. Campo Grande: UFMS. vol. 1, p. 87 .

TADDEI, VA., VICENTE, EC., PULCHÉRIO-LEITE, A. and MERCANTE, MA., 2003. Morcegos (CHIROPTERA: MAMMALIA) da região do Instituto de Pesquisa do Pantanal, sub-região do Rio Negro, MS, Brasil. Ensaios e Ciência, vol. 1, no. 1, p. 681-687. Ed. especial.

TEIXEIRA, RC., CORREA, CE. and FISCHER, E., 2009. Frugivory by Artibeus jamaicensis (Phyllostomidae) bats in the Pantanal, Brazil. Studies on Neotropical Fauna and Environment vol. 44 , no. 1, p. 7-15.

TOMAS, WM., CÁCERES, NC., NUNES, AP., FISCHER, E., MOURÃO, GM. and CAMPOS, Z., 2009. Mammals in the Pantanal wetland, Brazil. In: JUNK, WJ., SILVA, CJ., CUNHA, CN. and WANTZEN, KM., Org. The Pantanal: ecology, biodiversity and sustainable management of a large neotropical seasonal wetland. Sofia: Pensoft Publishers. p. 127-141.

VICENTE, EC., TADDEI, VA. and JIM, J., 2005.Características morfológicas externas distintivas de Myotis albescens, M. nigricans, M. simus e M. riparius (Chiroptera;Vespertilionidae). Ensaios $e$ Ciência, vol. 9, no. 2, p. 293-304.

VIZOTTO, LD. and TADDEI, VA., 1973. Chave para determinação de quirópteros brasileiros. Revista da Faculdade de Ciências e Letras de São José do Rio Preto - Boletim de Ciências, no. 1, p. 1-72.

WILLIG, MR., 2000. Latitude, common trends within. In LEVIN, SA., Ed. Encyclopedia of biodiversity. Burlington, Massachusetts, USA: Academic Press. vol. 3, p. 701-714.

WILLIG, MR., PRESLEY, SJ., OWEN, RD. and LÓPESGONZÁLES, C., 2000. Composition and Structure of Bat Assemblages in Paraguay: A Subtropical-Temperate Interface. Journal of Mammalogy, vol. 81, no. 2, p. 386-401.

WILSEY, BJ. and POTVIN, C., 2000. Biodiversity and ecosystem functioning: importance of species evenness in an old field. Ecology, vol. 81, p. 887-892.

ZORTÉA, M. and ALHO, CJR., 2008. Bat diversity of a Cerrado habitat in central Brazil. Biodiversity and Conservation, vol. 17, no. 4, p. 791-805. 